\title{
The Sessional Papers: Last Phase
}

\author{
By EDGAR L. ERICKSON
}

$\mathrm{T}_{\mathrm{s}}$ The British House of Commons Sessional Papers of the eighteenth and nineteenth centuries are, as I wrote seven years ago in the Library Journal (Jan. I, 1953), "the richest and most important collection of printed government records in existence in any country." With no complete set of these documents in existence anywhere, the program of republication, which I as editor had undertaken, presented problems of locating, identifying, collating, reassembling, editing, and manually foliating the more than eighty thousand separate publications, totaling 4,600,000 pages, which developed into a - task of extraordinary proportions and involved complexity.

The unusual editorial burden imposed by this program developed from the sheer mass of the documents, the lack of a master list and of a master collection fully collated, and the limited information concerning individual papers in the Journals and Votes of the House, about the only sources from which one may learn of official action on a paper. Questions such as these presented the ever recurring problems that had to be resolved: Does the table of contents of each volume list all of the papers of the volume? Do papers listed in the composite annual and period indexes but not in the tables of contents of volumes belong in the collections? Do papers bound in the volumes and listed in the tables of contents thereof or in the indexes or in both but which are not recorded in the Journals and Votes as having been ordered to be printed belong in the collections? Do papers recorded as ordered to be printed in the Journals and Votes which are not listed in the tables of contents or in the indexes or both belong in
Dr. Erickson is Professor of History, University of Illinois.

the collections? When the allotment of pages for a paper in the volume table of contents exceeds the actual number of pages of the paper bound in the volume is the table of contents incorrect or the paper incomplete? When the title printed on a paper differs from the title in the table of contents or in the indexes or in the Journals and Votes is the error in the title or in the paper? How can eighteenthand early nineteenth-century papers on which the numbers are not printed be positively identified? How are nineteenthcentury papers whose numbers are preceded by a zero and decimal point to be regarded? How can the Irish papers be distinguished from those of the British government in the early years of the nineteenth century? What should be done about papers ordered to be printed but which are reported to have been withdrawn? How can the complete text of a paper be ascertained when it contains plates, plans, charts, maps, designs, etc. for which pagination was not allowed in either the paper or in the collection volume tables of contents, and which, if listed at all, are listed obscurely in the index or table of contents of the paper? And so on ad infinitum might the list be continued.

As the slow, and at times agonizing, drudgery of moving the mountain proceeded, a point was finally reached when the end was actually in sight, except for a few elusive items which one suspected might be lost to posterity. In the case of the republication of the House of Com- 
mons Sessional Papers, 1731-1800, Second Series, commonly known as the Abbot Collection, and the nineteenth-century annual series, 1801-1900, this beginning of the end was reached when all except 128 out of approximately 2,200 papers in the Abbot Collection and 17 out of approximately 80,000 papers of the nineteenth-century collection had been collated and processed for republication. In England during the summer of 1959 the editor was able to locate the missing items. As a result it is now possible to complete the publication of these parliamentary collections. Done at a cost of nearly one-half million dollars under the editorship of the author of this article, the Readex microprint edition now for the first time makes available complete collections of the Second Series, 17311800, Abbot Collection, and of the annual series, 1801-1900, of the British House of Commons Sessional Papers, collections which heretofore have not existed complete in any library in the world.

The move to reprint the Sessional Papers was initiated by the editor in 1938. On the strength of data gathered in support of a publication plan, the Executive Council of the American Historical Association endorsed the program and established a special Committee on the British Sessional Papers-an affiliate of the Committee on Historical Source Materials-to carry it out. The special committee, in turn, entered into an agreement with the Readex Microprint Corporation for the publication of the Sessional Papers in microprint, a then revolutionary medium of printing-press printing at high reduction. ${ }^{1}$ The papers were to be printed on six-by-nine inch cards of permanent record quality, and, insofar as possible, the format was to follow the decimal arrangement of one hundred micropages on each card. The Readex company agreed to finance the program

\footnotetext{
1 The process was developed by Albert Boni, New York, during more than twenty years of research. See Edgar L. Erickson, "Microprint: A Revolution in Printing," The Journal of Documentation, VII (1951), 184-87.
}

on a self-liquidating basis upon being assured an initial minimum of twentyfive prepublication subscribers.

The work proceeded rapidly at first, for in 1942 the papers for the years 1821-25 inclusive were published and released. ${ }^{2}$ Then came the war with its stifling shortages of materials. Unforeseen technical difficulties and legal and financial troubles added further to the complications, all of which caused a stalemate in operations for several years. Meanwhile the work of collating and editing continued at the central base of operations in the New York Public Library, and, once the Readex company had cleared up its problems, the bulk of the Sessional Papers was published and distributed in the relatively short period extending from 1951 to $1957 .^{3}$

By 1958, consequently, only those papers that could not be located in repositories in the United States and Canada, or which foreign agents had not succeeded in finding for us in England, remained to be published. As time elapsed it became evident that the work of finding the missing papers could not be delegated successfully to agents abroad, and that if the program were to be completed the editor would have to go to England and perform the necessary search, research, and leg-work of beating the bushes for the missing items. This he did while on sabbatical leave from the University of Illinois in the spring and summer of 1959.

\section{The Abbot Collection}

The Abbot Collection of eighteenthcentury papers was assembled by Luke Hansard, printer for the House of Commons, under the direction of Charles

\footnotetext{
2 Subsequently, after World War II, the first micro print edition for the years 1821-25 was withdrawn from circulation and reissued so as to give the subscribers benefit of improved technical advances in printing.

3 The bulk of the load of locating the papers in the United States and Canada and of preparing the papers United States and Canada and of preparing the papers Mrs. Albert Boni, managing editor, without whose tireless and gigantic efforts this program never could have been completed. Credit is also due Dr. Erica Muller, who was responsible for preparing the papers for the years $1821-44$ for microcopying.
} 
Abbot (Lord Colchester), Speaker of the House, $1802-17,{ }^{4}$ as part of a broad program of collation and reprinting with the view to making the papers readily available for members of the Commons. ${ }^{5}$ Until that time the papers had not been numbered, collated, and bound for general use. ${ }^{6}$ The papers had been, and continued to be, published in small-folio size and the surplus copies were stored in government warehouses. ${ }^{7}$ As time elapsed members of Commons had found it increasingly difficult to obtain the papers of previous years. Mr. Hansard had a considerable stock of eighteenth-century papers in his warehouses, and from these stocks he assembled for the period 17311800 four sets of the original papers, one each for the Speaker's Gallery, for the Clerk of the Journal to be kept in his office, and for the Clerk of the Journal for use by the members of Commons, and for the British Museum. ${ }^{8}$ Mr. Hansard also assembled in annual series the original papers for the nineteenth century. This series began in 1801 and was bound according to a subject classification and grouping that was considered most advantageous for use by Commons and the government departments. The decision to bind the eighteenth-century papers in a composite arrangement covering the century and the nineteenth-century papers in an annual composite series

4 Second Report from the Select Committee on Committee Rooms and Printed Papers, H. C. Sess. Paps. 1825 (515): $3-4, \mathrm{~V}: 13-14$.

5 Report of Lord Glenbervie from the Committee Ap. pointed to Enquire into the State and Condition of Printed Journals of the House, and General Indexes thereto, and also Volumes of Printed Reports, \&c.; Jour. H. C., 1802-3, LVIII, 638, 653-58. Third Report from the Select Committee on Committee Rooms and Printed Papers, H. C. Sess. Paps., 1825 (516), $3 \mathrm{ff}$ $\mathrm{V}: 23 \mathrm{ff}$. Classification of the Parliamentary Papers and Breviate of Their Contents, \&C., H. C. Sess. Paps. a Breviate of Their Contents,

The papers published by order of the House of Commons in the eighteenth century were grouped and numbered by groups when the Abbot Collection was collated under the direction Charles Abbot, Speaker of the House. See Catalogue of Papers Printed by Order of the House See Catalogue of Papers Printed by Order of the House of Commons from the years 1731-1800

7 H. C. Sess. Paps., 1825 (515), 4, V:14 and (516), 4, $\mathrm{V}: 24$.

${ }^{8}$ App. N. I: Memoir on a Selection of Parliamentary Reports and Papers, in Continuation of Fifteen Volumes, H. C. Sess. Paps. 1825 (516), 9ff, V:29ff; (515), 2-7, V:12-17; and Catalogue of Books of the Library of the House of Commons, H. C. Sess. Paps., $1830(80)$, iff, IV:142ff stemmed not only from the fact that 1801 marked the beginning of a new century but that it also was the year that Ireland entered into a legislative union with Great Britain, thereby making a new sessional papers series essential. ${ }^{9}$

The resulting Second Series (110 vols.) of the eighteenth-century papers was arranged chronologically for the century into three serial groups. There are 963 Bills, 174 Reports, and 1,032 Accounts and Papers. The Bills comprise Vols. I to XXX of the Second Series; the Reports, Vols. XXXI to LXVIII; and the Accounts and Papers, Vols. LIX to CX. ${ }^{10}$ In assembling the four sets of the Abbot Collection Mr. Hansard prepared handwritten tables of contents for each of the volumes of the series and then proceeded to collect the papers for binding. In this endeavor he was not able to realize complete fulfillment of his expectations, for in each of the Abbot Collections there are quite a large number of the papers listed in the tables of contents of the volumes as being out of print. A careful examination of the Abbot Collections held by the House of Commons, the British Museum, and the University College of London will supply anyone interested with convincing evidence that when in the final gathering of the papers for binding, as directed by the Speaker of the House, Mr. Hansard found only one original copy of a particular paper, he placed it in the collection for the Speaker's Gallery. As a consequence, the Abbot Collection in the Speaker's Gallery became the most complete of the four sets of original papers collated by Mr. Hansard, for there were quite a large number of papers of which but single copies could be found.11 On the other hand, from the standpoint of completeness there is little to choose between the Abbot Collections at the House of Com-

H. C. Sess. Paps., 1825 (515), 7, V:17 and (516), $1-11,12 \mathrm{ff}, \mathrm{V}: 20-31,31 \mathrm{ff}$.

10 See the Cataloaue of Papers Printed by the Order of the House of Commons from the Years 1731-1800 (1807).

11 See below in section on Bills. 
mons and at the British Museum. While the Commons collection is probably a little more complete in original papers, the British Museum has endeavored to fill the gaps in its collection with microfilm copies of the missing papers.

The Abbot Collection in the Common's library today probably represents a combination of the two original sets that Mr. Hansard prepared for the Clerk of the Journals: one set to be retained in the Journal Office and the other to be for use by the members of the Commons. The latter went into the Commons library when space was allotted for a library in $1818 ;^{12}$ the former also seems to have been transferred from the Journal Office to the Commons library upon the recommendation of the Select Committee on Printed Papers in 1825. The committee found that since the set of printed papers then in the custody of the Clerk of the Journals was more complete than the set in the care of the librarian of the House, it (the former) should be "transferred to the library of the House as a place of more convenient access and reference." 13 Thus on the eve of the burning of the parliament on 16 October 1834 , there were two of the Abbot Collections in the Commons Library. But the official reports of the books destroyed in and saved from the fire are strangely lacking in information concerning what happened to the two Abbot Collections in the Commons library, though these reports do enumerate the other House of Commons and Lords Papers and Journals that were lost in and salvaged from the fire. ${ }^{14}$ Fortunately, Professor H. Hale Bellot, as a result of his extensive research in parliamentary printing, has concluded that one of the four original

\footnotetext{
12 Report from Select Committee on the Present State of the Library of the House of Commons, H. C. Sess. Paps., 1830 (496), 10-11, IV:44-45 (Evidence of Henry Ley).' Until 1818 a small library under the custodianship of the Clerk of the Journals was available to members of Commons; the great increase in parliamentary papers caused a much larger library under a full time librarian to be established in that year.

${ }_{13}$ H. C. Sess. Paps. 1825 (516), 4, V:24.

14 Report from the Standing Committee on the Library
}

Abbot Collections was destroyed in the 1834 fire. ${ }^{15}$ In the light of this information one may conclude that the Abbot Collection in the House of Commons library today is one or the other of the two original collections assembled by $\mathrm{Mr}$. Hansard for the Clerk of the Journals, or, possibly is a part of both, for it is improbable that one was entirely destroyed and the other escaped completely intact from the conflagration. ${ }^{\mathbf{1 6}}$

\section{Speaker's Gallery Abbot Collection}

It is not likely that library circles in London were aware that the Abbot Collection in the Speaker's Gallery was the most complete of these original collections. If that fact had been known it is improbable that the Speaker of the House would have consented to the loan of the Speaker's Gallery set to the University College library early in the present century. ${ }^{17}$ It is not quite fitting that either the House of Commons or, for that matter, the British Museum should be placed in the position of second best in the matter of parliamentary papers holdings.

The discovery, or rediscovery, of the superiority of the Speaker's Gallery Abbot Collection over the other original sets resulted from a train of thought inspired by parliamentary pageantry. When the editor made his first visit to parliament for the purpose of discussing with the librarian of the House of Commons the problem of locating the missing papers, he arrived at the river end of the lobby between the two houses but a few moments before the passing of the Speaker on his way to convene Commons.

\footnotetext{
of the House of Commons, together with the Minutes of Evidence and Appendices, H. C. Sess. Paps., 1835 (104), 16-22 (Apps. A, B, C), XVIII:121-28.

15 H. Hale Bellot, "Parliamentary Printing, 1660 1837," Bulletin of the Institute of Historical Research (London), XI (1933-34), 94.

10 The books in the lower library that were saved were thrown out the windows into Cotten Garden and salvaged a fter the fire. H. C. Sess. Paps., $1835(104): 3$, XVIII: 107 .

17 The present staff of the University College Library was not aware that the library had the Speaker's Gal lery Abbot Collection; nor do they have the records that show how the collection was obtained by University College.
}

COLLEGEANDRESEARCHLIBRARIES 
In respectful silence he took position along the wall and in wonderment observed the guard close by rise up on his toes and in full resonant voice shout, "The Speaker!" The people in the lobby stepped to the sides of the passageway and froze at attention; the area became strangely quiet as the Speaker, preceded by a guard and a mace-bearer, each attired in the medieval regalia of his office, debouched from a doorway at the end of the lobby and in measured steps moved like ghosts along the corridor to the House of Commons. This brief act of pantomimic medieval pageantry brought home to the editor a new appreciation of the majestic sovereignty of the Speaker over his domain in parliament. Unaware at the time that the episode of the passing of the Speaker was to become a clue to the locating of missing sessional papers, the editor was then ushered to the office of the librarian.

Before seeking the assistance of the librarian of Commons, the editor had carefully checked the list of missing papers against the Abbot Collection at the British Museum. This check had yielded fruitful, but by no means complete, results. In the British Museum collection a number of the missing items were noted as being located in the Speaker's Gallery set. The editor supposed, naturally, that the Speaker's Gallery set would be in the House of Commons, and that it would most likely be the one used by the members. Holding this view he began his survey of the Commons Abbot Collection which the librarian graciously made available to him, only to discover that the papers noted at the British Museum as being in the Speaker's Gallery set were usually missing in the Commons set as well. It therefore became obvious that the Speaker's Gallery set was not the one in the Commons library. Meanwhile it had finally dawned upon the editor that the same Speaker who commanded the awesome respect of the House would also have had assembled for his use the most complete Abbot Collection that it was possible for Mr. Hansard to arrange. Where then was the Speaker's set? This query addressed to a staff member of the Commons library elicited an equivocal reply: "Try the University College of London." At University College the editor found the Speaker's Gallery Abbot Collection, and in it were a large majority of the missing papers that were not in either the British Museum or Commons sets. ${ }^{18}$ The discovery of both the location and the superior completeness of the Speaker's Gallery set was surprising news to the libraries holding original Abbot Collections.

\section{Aвbot Collection: Bills}

Of the 963 Bills in the Abbot Collection, sixty-three were needed to complete the Readex microprint edition. Of this number all except twenty-one were found in the British Museum and Commons sets; the twenty-one were found only in the Speaker's Gallery set. By short title they are:

No. 26 (1745): A bill to obviate difficulties in the laws touching poor removals, overseers accounts, \&c., 12p.

No. 105a (1758): A bill obliging parishes to keep registers of births, \&cc., and to raise a fund for the foundling hospital, 16p.

No. 111 (1759): A bill amending acts for the preservation of highways and roads, $28 \mathrm{p}$.

No. 120b (1760): A bill better ordering the militia forces in Scotland, 36p.

No. 128b (1762/3): A bill concerning Westminster paving (with amendments), 26p.

No. 135a (1764/5): A bill for allowing the exchanges of real estates by ecclesiastical persons, corporations, and trustees for charitable uses, $8 \mathrm{p}$.

No. 135b (1764/5): A bill to encourage and facilitate marriages, $8 \mathrm{p}$.

18 Notwithstanding the excellence of the University College Speaker's Gallery Abbot Collection, vols. 31, 40, 56, 57, 58 (all Reports vols.), and 94 and 95 (Accounts and Papers vols.) are missing. It may be that these were withdrawn from the Collection to complete the were withdrawn from the Collection to complete the
House of Commons Abbot Collection losses suffered in House of Comm
the 1834 fire. 
No. 135c (1764/5): A bill to explain Act 12 of William III, for preventing inconveniences that may happen by the privilege of parliament, $4 \mathrm{p}$.

No. 135d (1764/5): A bill for the better relief and employment of the poor, $36 \mathrm{p}$.

No. 135e (1764/5): A bill for additional duties on silk, \&c., 8p.

No. 135f (1764/5): A bill for regulating the currency of notes and bills issued by Scotch banks, $8 \mathrm{p}$.

No. 135g (1765): A bill enabling ecclesiastical persons to exchange their lands (with amendments), $6 \mathrm{p}$.

No. 135h (1765): A bill enforcing uniformity to the standards of weights and measures, 22p.

No. 135i (1765): A bill to enlarge the power of Westminster paving acts, 24p.

No. 135k (1765): A bill to amend laws touching elections, 32p.

No. 136 (1765): A bill to restrain the ill practice of brokers, $6 \mathrm{p}$.

No. 138 (1765): A bill to continue Act 30 of Geo[rge] II for the more effectual amendment of highways and roads, $7 \mathrm{p}$.

No. 140 (1765): A bill to quiet the present possession of leases from ecclesiastical persons, $4 \mathrm{p}$.

No. 143 (1765): A bill for the better relief and employment of the poor (with amendments), 38p.

No. 149 (1766): A bill to explain acts for the amendment and preservation of highways, $8 \mathrm{p}$.

Two papers in the Bills group, nos. $421 \mathrm{a}$ and $421 \mathrm{~b}$ of 1782 , present an enigma that has not been entirely cleared up. No. $421 \mathrm{a}$ is listed in the Catalogue of Papers $\ldots 1731$ to 1800 (1807), and its full title is "A bill inflicting pains and penalties on Sir Thomas Rumbold, Baronet, and Peter Perring, Esquire, for certain breaches of public trust, and high crimes and misdemeanors, committed by them whilst they respectively held offices of governor and president, counsellors and members of the select committee, of the settlement of Fort Saint George, on the coast of Coromandel, in the East Indies." 19 In the same Catalogue paper no. $421 \mathrm{~b}$ is entered as being "the same" as no. $421 \mathrm{a}$, and in the three Abbot Collections in London the texts of the two papers are identical, both being forty-one pages. Since the Journals of the House of Commons for 1782 contain no record of an order for a second printing, there is no apparent reason why a duplicate of the original bill should be included in the collection, aside from the fact that Mr. Hansard put it there. For that reason alone, no. $421 \mathrm{~b}$ as produced in the Readex microprint edition is a duplicate of no. $421 \mathrm{a}^{20}$

Logic dictates that at least two other papers might better have been used by Hansard as no. 421b than the one selected. The first is a bill introduced 3 June and given royal assent on 1 July 1782, entitled "A bill to provide that the proceedings on the bill now pending in parliament for inflicting certain pains and penalties on Sir Thomas Rumbold, Baronet, and Peter Perring, Esquire, for certain breaches of public trust, and high crimes and misdemeanors...., shall not be discontinued by any prorogation or dissolution of parliament." 21 The purpose of this bill was to prevent discontinuance of action against Sir Thomas Rumbold and Peter Perring by reason of a prorogation or dissolution of parliament. In a series of resolutions embodied in the original bill, no. $421 \mathrm{a}$, these officials, formerly at Fort St. George, were charged with acquiring funds not properly accounted for to the East India Company, and with failure to act offi-

19 A bill for inflicting pains and penalties on Sir Thomas Rumbold, \&c. was ordered 29 April, 1782; presented and read for the first time 7 May; and ordered to be printed on 8 May. See Jour. H. C., XXXVIII, 961.987 , and 991 , respectively.

961 . 987 , and 991 , respectively. 20 For papers no. $421 \mathrm{a}$ and
$1731-1800$ (2nd Series), XII.

I Jour. H. C., XXXVIII, 1030, 1042, 1046, 1050-51, 1054-55, 1130 and Public General Acts, 22 Geo. III, Cap. LIX, 947-48. 
cially so as to prevent the incursions of Hyder Ali in the Carnatic in $1780 .^{22}$ Parliament at this particular time was extremely sensitive about the corruption in India and was of no mind to let the officials involved by the bill escape punishment by reason of prorogation or dissolution. The bill insuring the continuance of action in the next session, though passed and approved, was never ordered printed, and, consequently, was not included in the Abbot Collection, ${ }^{23}$ though it logically could be considered more appropriate as no. $421 \mathrm{~b}$ than the one so designated by Mr. Hansard. In the nineteenth century such a bill would have been ordered printed and included among the parliamentary papers of the session.

A second paper that might well have become no. $42 \mathrm{lb}$ was also one that grew out of the original bill, no. 42la in the Abbot Collection. The original bill, as may be noted from the title, was a bill of pains and penalties involving Sir Thomas Rumbold and Peter Perring. ${ }^{24}$ Each of the accused in separate petitions protested against the irregular action and demanded representation by counsel at the bar of the House. ${ }^{25}$ This request was granted, for at the second reading of the bill in January 1783 there began a series of hearings on the bill that continued until June. On 2 June 1783 it was

29 For an exposition of the affairs in India that led to the action in Commons against Sir Thomas Rumbold, Baronet, and Peter Perring, Esquire, see the resolutions of 29 April 1782 of the "Committee on Secrecy Relating to the Affairs of the East India Company," George Howard, Chairman; Jour. H. C., XXXVIII, 956-61.

23 See n. 21.

$24 \mathrm{~A}$ bill of pains and penalties resembles a bill of attainder in purpose and procedure, but imposes a lesser punishment than death. These bills had become rare by the late eighteenth century. Notable cases in which such a bill was passed are those involving the Bishop of Atterbury in 1722, and Queen Caroline, wife of George IV in 1820. This bill against Sir T. Rumbold and Peter Perring is unusual in that it is introduced in the House of Commons instead of the House of Lords. It did not pass.

${ }_{25}$ For the petitions of Rumbold and Perring requesting separate hearings and counsel on the charges in the bill, and for the granting of the petitions see Jour. H. C., XXXVIII, 963-64, 1003-4, 1005, 1039; and XXXIX, 31-32, 82, 119-20, 143, 171, 178, 194, 237, 255, $261,272,346,354,369,371,398,400,405,411,419-20$, $422,427,430,448,454$. See also petitions of $\operatorname{Sir} T$. Rumbold and Peter Perring, $15 \mathrm{May}$ and $17 \mathrm{May} 1782$, respectively; Jour. of the House of Lords, XXXVI, 498,503 . "ordered that such a number of minutes of evidence taken at the bar of the House and of the proceedings of the House on second reading of the bill for inflicting certain pains and penalties on Sir Thomas Rumbold and Peter Perring .... be printed as shall be sufficient for use of the members of the house." 26 Notwithstanding the printing order, Mr. Hansard did not include this paper among either the Bills or the Accounts and Papers of the collection. ${ }^{27}$

\section{AbBot Collection: Reports}

Under the Reports only those papers of the collection that were reports of committees and that were ordered printed by Commons are included. Of the total of 174 reports, sixty-five remained to be located in England. Only after considerable searching were the missing reports found, for the three original Abbot Collections, as in the case of the bills, did not supply all of the reports. All told, five major snags were encountered to complicate this phase of the collation, and a discussion of these difficulties will be useful to others who may attempt to assemble Abbot Collections.

Probems one and two may be taken together. They embraced the locating, the identifying, and the establishing of the correct text. of the reports of two committees on India that took evidence and reported in the years 1772 and 1773 . The first of the committees was appointed "to enquire into the nature, state, and condition of the East India Company, and the British affairs in the East Indies," for the period from the beginning of the company to 1772 . The in-

20 Jour. H. C., XXXIX, 456.

27 Technically, the minutes of evidence taken in connection with the hearings on the bill to impose pains and penalties on Sir Thomas Rumbold and Mr. Peter Perring would have appeared in the Accounts and Papers group of the Abbot Collection, had they been included in the Collection by Mr. Hansard. It can be argued, therefore, that the minutes of evidence taken on the bill have no place among the Bills. The fact is, however, that the minutes were not included among the Accounts and Papers, and that being the case a paper containing these minutes more appropriately should have been put in the Collection as no. $421 \mathrm{~b}$ rather than a duplicate of the bill which appears as both no. 421a and no. $421 \mathrm{~b}$. 
vestigations, roughly, were to cover the activities of the company with the native powers and foreign powers, the activities of the company's servants, the conduct of the directors in the keeping of accounts and in the control of servants, and the abuses arising from the constitution of the company. ${ }^{28}$ The findings of the committee were published in five reports designated as papers nos. 15 to 19 in the Abbot Collection. ${ }^{29}$ The First Report (No. 15) was made to Commons on 26 May 1772, and it dealt with conditions in Bengal under Clive. The motion for the printing of the report "passed in the negative," but the report, together with its fifteen appendixes, was printed in the Journals of the House of Commons as part of the proceedings of the day. ${ }^{30}$ In 1773, however, the First Report was published separately (apparently by the government printer, because it was done in small-folio) for private sale by "T. Evans, at No. 54, in Pater-Noster Row, and W. Davis, the Corner of Sackville Street, Piccadilly." 31 The text of the 1773 edition is identical to that in the Journals, but not to the text of the "First Report of the Committee to Enquire into the Nature, State and Condition of the East India Company and the British Affairs in the East Indies," printed in the House of Commons Sessional Papers, 1715-1801 (First Series) III, 135-262, which is an abridgement of the original text, in that the Appendix 15 of forty-one pages has been omitted. When Mr. Hansard prepared the Abbot Collections, he included the First Report of the above committee in the collection as paper no. 15, but he did not succeed in locating any copies of the 1773 edition. In each of the original Abbot Collections the entry, "Out of Print," appears in the table of contents of Vol. II, Reports, for paper no. 15.32

\footnotetext{
2826 May 1772, Jour. H. C., XXXIII, 792.

23 Catalogue of Papers 1731-1800, Reports, II

30 Tour. H. C., XXXIII, 792, 792-913.

31 The 1773 edition of the First Report of the Committee to Enquire into the Nature, State and Condition of the East India Company, \&c. consisted of forty-seven pages of report and 153 pages of appendixes.

os The original sets are at University College, the
}

Also missing from the original Abbot Collections in London, is paper no. 16, the Second Report of the Committee on the Nature, State and Condition of the East India Company and the British Affairs in the East Indies. Although the paper is referred to as the Second Report of the committee, it is really a special report that the committee was called upon to make on a "petition of Gregoire Cojamaul, late of Bengal, in behalf of himself and other Armenian merchants," together with the letters referred to in the report. ${ }^{33}$ This Second Report was made to Commons also on 26 May 1772; it was not ordered to be printed; but it was printed in the Journals as part of the proceedings of the day. ${ }^{34}$ In the same year, however, this Second Report was printed separately in quarto for private sale by $\mathrm{S}$. Blandon, Pater-Noster Row. ${ }^{\mathbf{3 5}}$ Aside from faulty printing in col. 2, p. 104 , the 1772 quarto edition is identical in text to the Second Report in the Journals. The illegible lines read: ‘. . Captain Harper took two parties of sepoys, and they to took me Prisoner, and carried me to Captain Harper's tent. He sent his Munthy to know the Reason why we came at such an improper hour." Aside from the text of the Second Report printed in the Journals, the quarto edition printed privately in 1772 seems to have been the only edition until the report was reprinted in Vol. III of the First Series of eighteenth-century Sessional Papers in 1803. Mr. Hansard failed to find copies of the 1772 edition of Second Report for the Abbot Collections, and in the table of contents of Reports Vol. II, paper no. 16, Second Report \&c., is recorded as "Out of Print."

The editor was about ready to conclude that the original 1773 and 1772 editions of the First and Second Reports of the

\footnotetext{
British Museum, and the House of Commons Library.

si. Tour. H. C., XXXIII. 792.

3426 May 1772, Jour. H. C. XXXIII, 914-44.

35 This Second Report of the Committee to Enquire into the Nature, . . of the East India Company, \&c. consisted of Minutes, pp. 1-77, Report, pp. 77-124.
} 
Committee on the Nature, State and Condition of the East India Company, bc., respectively, were no longer extant, when he located a copy of each report in the Goldsmiths' Library of the University of London. ${ }^{36}$ These have been used for duplication in the microprint edition.

The "Third, Fourth and Fifth Reports of the Committee on the Nature, State and Condition of the East India Company" are papers nos. 17, 18, and 19, respectively, of the Abbot Collection, and they are all to be found in the original collections, though they were not all correctly collated. ${ }^{37}$

The second of the two committees on India was known as the "Committee on Secrecy appointed to enquire into the State of the East India Company." The purpose of this committee was to inspect the books and accounts of the company and to report to the House of Commons what they found in respect to debts, credits, and management of the company. ${ }^{38}$ This committee issued nine reports which became papers nos. 20 to 29 of the Abbot Collection. Paper no. 24 consists of an Appendix to the Fourth Report (no. 23). ${ }^{39}$

Of this group of reports the original edition of only no. 20, the First Report of the committee on secrecy, seems to have disappeared. That a small-folio official edition of this report was published may be ascertained from the Journals. On 7 December 1772 the committee on secrecy made its first report. The report was not printed in the Journals as part of the proceedings, and it was not ordered to

\footnotetext{
36 For "First Report of the Committee on the Nature, State and Condition of the East India Company, 26 May 1772," see Report from the Select Committee'Appointed by the House of Commons... Fifth Session of pointed by the House of Commons.; Fifth Session of the Thirteenth Parliament, to enquire into East India For the "Second Report of the Committee on the $\mathrm{Na}$ ture, State and Condition of the East India Company, \&c." see Report from the Select Committee. . to enquire into the Nature, State and Condition of the East enquire into the Nature, State and Condition of the East India Company (1772), Goldsmiths' Library, 1772 fol. tion; and $H$. C. Sess. Paps., 1731-1800, (Second Series),

Reports, Vol. II.

38 Dec. 1772, Jour. H. C., XXXIV, 27, col. 1.

a See n. 37 .
}

be printed as a separate paper until 28 June 1773 , at which time the other reports of the committee were similarly ordered to be printed.40 Presumably, the First Report from the Committee of Secrecy was printed by Mr. Hansard as ordered by the House, but copies were not available for the original Abbot Collections. The editor did not succeed in locating an original 1773 edition of the repert for the Readex microprint edition; in this one case he had to settle for the reprinted edition of the First Report that is in Vol. IV, pp. 1-14, of the House of Commons Sessional Papers, 1715-1800, (First Series). ${ }^{41}$

Notwithstanding the fact that the reports of the two committees on India, namely, "the committee to enquire into the Nature, state and condition of the East India Company," and "the Committee on secrecy to enquire into the state of the East India Company," were reprinted in the First Series in 1803-1804, and that the reports of the two committees were correctly listed in the Catalogue of Papers . . 1731-1800 published in 1807, Mr. Hansard, or the party working under his direction, failed to get the reports of these two committees properly collated in the three original Abbot Collections. The Speaker's Gallery set at University College not only lacks reports nos. 15,16 , and 20 , but in the table of contents of the Reports, Vol. II, no. 16, the Second Report of the first of above committees on India, is incorrectly listed as no. 21 , the Second Report of the second of the above committees on India; and no. 18, the Fourth Report of the first committee, as no. 23, the Fourth Report of the second committee. In the Commons set reports nos. 15, 16, 20, 21, 22,23 , and 24 are missing, and no. 19 is bound in Vol. III instead of II. The British Museum set lacks nos. 15, 16 and 20 .

\footnotetext{
407 Dec, 1772 , Jour H C. XXXIV, 27, col. 1

41 This paper was copied for the micronrint edition 41 This paper was copied for the micronrint edition
from the $H$. C. Sess. Paps. 1715.1801 (First Series), IV, held by the Institute of Historical Research, Senate House, University of London.
} 
The reasons for the confusion in the identification of the reports of the two committees on India may be attributed to the fact that the committees were covering approximately the same ground at the same time in their investigations; that there was delay in the publication of some of the reports; that the titles of some of the reports were incorrect in their initial printing; and that the failure of Mr. Hansard to obtain original editions of some of the reports made difficult the task of identifying correctly the reports he did locate. The puzzling question that arises is why did not the collators refer to the reprinted reports in the First Series, which appear to have been published before or simultaneously with the collation of the Abbot Collections, for the correct identification of the reports?

A third major problem encountered in the collation of the Reports pertains to paper no. 112, Seditious Societies (1794). This is a report from a committee of secrecy, composed of twenty-one members of the House, elected by ballot and headed by William Pitt, appointed to examine books and papers primarily of the Society for Constitutional Reform and of the London Corresponding Society. ${ }^{4}$ The committee made its first report to the House on 16 May 1794 and on the basis of its findings introduced bills that became laws empowering the government to secure and detail persons suspected of conspiracy against His Majesty and his government.43 The report was published in the Journals as part of the proceedings of the day, and on the following day the House ordered that it be printed "in such number as shall be sufficient for use of the members." 44 If this printing for the members was done, copies were not found by Mr. Hansard for the Abbot Collections, for the copy of the report in the Commons collection is

\footnotetext{
42 Jour. H. C., XLIX, 589-90, 594, 600.

43 Ibid., 600-610

4 Ibid., 613.
}

of quarto size rather than of the official small-folio. The quarto edition of the report is a forty-six-page paper published privately for sale by J. DeBrett in 1794.45 Only the Commons set contains a copy of report no. 112, Seditious Societies, and this a quarto 1794 edition. Even though there is some doubt concerning the official character of the quarto edition of no. 112 , for want of a more official copy it is being duplicated for the Readex microprint edition.

The fourth and fifth major problems concerning the collation of the Reports involved the locating of the supplementary plans that were missing from the reports from committees for the improvement of the Port of London, and what to do with evidence taken by one of these committees, which though ordered to be printed had not been included in the Abbot Collection.

Beginning in 1796 and continuing into the nineteenth century there were several bills introduced in Commons that had for their purpose the improvement of the Port of London. Committees held hearings on these bills, gathered evidence, and submitted reports that were printed upon the order of the House in small-folio. The report no. 129 of 1796 of the Abbot Collection, was that of a "committee appointed to enquire into the best mode of providing sufficient accommodation for the increased trade and shipping of the Port of London." 46 The report consists of 216 pages of minutes of evidence, together with Appendixes A-Z, Aa-Zz, and Aaa-Ppp. In the Appendixes are Plates I to XIX (Plans nos. I to 19). Three years later another committee was appointed "to consider the evidence taken on the bills for the improvement of the Port of London." 47 Thís commit-

\footnotetext{
45 See $H . C$. Sess. Paps., 1731-1800 (Second Series), XLIV (Reports, XIV), no. 112.

46 For report no. 129, 13 May 1796 see $H$. C. Sess. Paps. 1731-1800 (Second Series), XLVII (Reports, Vol. XVII).

477 May 1799, Jour. H. C.. LIV, 517-18. See also H. C. Sess. Paps., $1731-1800$ (Second Series), XLVII, (Reports, XVII).
}

COLLEGE ANDRESEARCH LIBRARIES 
tee made its First Report (no. 153), 1 June 1799, consisting of six pages and forty pages of appendixes. In this report there were no plates or plans. The same committee made its Second Report on 11 July 1799; it consists of two papers (nos. 154 and 155), totaling 166 pages. No. 154 is a brief report of sixteen pages, and no. 155 is appendixes, a part of which are Plates Nos. I to XIV (Plans nos. 20 to 37).48 The Third Report of the committee is no 167,28 July 1800 , of 149 pages, the first twenty pages being report proper and the remainder appendixes. ${ }^{49}$ In the appendixes are Plates Nos. I to XXI (Plans nos. 38 to 62). A further report was made in 1801 but that report is part of the nineteenth-century Sessional Papers. ${ }^{50}$

Of the above reports it may be noted that no. 129 of 1796 , no. 155 of 1799 , and no. 167 of 1800 each has plates or plans as part of the appendixes. The plates or plans for no. 129 are complete in the original Abbot Collections; but for nos. 155 and 167 the plates or plans are nearly all missing. In each of the above reports the numbered plates have also been assigned plan numbers coinciding with the numbers of the plans in a Book of Plans. These plan numbers have been added by hand in black ink at all places in the reports and appendixes where references are made to the numbered plates. The repeated references to a Book of Plans indicated that such a book must exist, but there was no such book with the Abbot Collections at either the University College or at the British Museum. The House of Commons Abbot Collection, like the other two original collections, contained only a limited number of the plates or plans of the Port of London reports. It began to look as though the

48 For reports no. 153, 1 June 1799; nos. 154-155, 11 July 1799 , see $H$. C. Sess. Paps., 1731-1800 (Second Series), LIII (Reports, XXIII)

49 For report no. 167,28 July 1800 see ibid., LVII (Reports, XXVII).

50 See Report from the Select Committee for the Im. provement of the Port of London, H. C. Sess. Paps., 1801 (102), III. missing original plates or plans would not be obtainable, when an inquiry by the editor addressed to a staff member of the Commons library turned up the mysterious Book of Plans. It is an extra-large master-volume containing the plans, numbered consecutively from one to sixty-five, of the reports on the improvement of the Port of London for the period 1796 to $1801 . .^{51}$ Plans twenty to sixty-two, inclusive, missing in the reports nos. 155 and 167 of the original Abbot Collections, will be supplied for the Readex microprint edition from the Book of Plans.

What to do with the two supplements of evidence taken in 1799 in connection with bills relating to the improvement of the Port of London is the fifth problem bearing on the collation of the reports. The first supplement is entitled Minutes of Evidence Taken at the Committee on the Bill for Rendering More Commodius, and for Better Regulating the Port of London, 11 February to 25 April 1799: Evidence, pp. 1-46; Appendixes (A-C), pp. 47-58; Further 'Minutes, pp. 59-80. The second of the supplements is entitled Minutes of Evidence Taken at the Committee on the Bill for Making Wet Docks, Basons, Ceels, and Other Works, for the Greater Accommodation and Security of Shipping, Commerce, and Revenue within the Port of London, 11 February to 25 April 1799 (Including the Plan of the London Docks produced and explained by Captain Shields), pp. 1-112. Also part of the supplement are Further Minutes, bc., 26 April to 7 May 1799 , pp. 113-374, consisting of a "Merchant's Plan" and Appendixes A to Z.52 Both of the above supplements were ordered to be printed by the House on 25 April and 7 May $1799,{ }^{53}$ and on the lat-

5. Book of Plans for the Improvement of the Port of London, 1796-1801. Plans nos. 63 to 65 inclusive are part H. C. Sess. Paps., 1801 (102), III.

59 These two supplements are unbound in the library of the University College of London.

53 Fr actions on the two supplements in Commons on 25 April and 7 May 1799 see Jour. H. C., LIV, 482-83, $517-18$. 
ter date the House appointed a select committee to consider all of the minutes of evidence reported to the House by the committee on the above "Port of London" and "Wet Docks and Basons" bills. ${ }^{54}$

The select committee made its First Report on 1 June 1799; its Second $R e$ port on 11 July 1799; and its Third Report on 28 July 1800 . These reports were papers nos. $153,154-155$, and 167 respectively, of the Abbot Collection. ${ }^{55}$ But the above minutes of evidence contained in the two supplements were not included in the collection, even though they were officially ordered to be printed. In order to make the minutes of evidence available to scholars, the two supplements are being published in the Readex microprint edition immediately following the Appendix of the First Report, no. 153. If the supplements were added to the Accounts and Papers group of the Abbot Collection, they would be lost for want of a listing in the Catalogue of Papers ... 1731 to 1800 ; by placing the supplements with the First Report from the Committee on the Improvement of the Report of London they can be located without special citation in the Catalogue, for they will serve as an appendix to the report made in consideration of these very minutes of evidence that compose the supplements.

\section{Accounts and Papers: Abbot Collection}

Papers not arranged under Bills and Reports were included under Accounts and Papers. The latter group includes papers pertaining to revenue, commerce, estimates and expenditures, other statements and accounts, and all papers printed by order of the House of Commons that were not proceedings of the House, such as narratives of particular transactions, treaties, diplomatic corre-

54 7 May 1799 , Jour. H. C., LIV, 517-18.

ธu See $n n .47,48,49$. spondence, papers respecting East India affairs, reports of the East India Company that were not select committee reports, reports of parliamentary commissioners, and minutes and evidence taken before committees of the House. Of the 1,032 papers under the above heading in the Abbot Collection, sixty-nine had to be found in England. Of this number only two papers became problems of extensive research: the others were available in the three original Abbot Collections, again with the Speaker's Gallery set at University College serving as the best source. ${ }^{56}$

The first of these problems involved paper no. 788. The paper consists of seventeen days of evidence taken between March and May 1794 by a House of Commons committee on the occasion of the second reading of a petition for the "Eau Brink and King's Lynn drainage bill." 57 Although the bill itself was not printed as a separate paper, ${ }^{58}$ the minutes of the evidence were. The full title of the bill is "A bill for improving drainage of the middle and south levels, part of the great level, and the low lands adjoining or near the river Ouze, in the county of Norfolk, draining through the same to the sea by the harbour of King's Lynn, in the said county, and for altering and improving the navigation of the said river Ouze, from or near a place called Eau Brink, in the parish of Wiggenhall Saint Mary's, in the said county, to the said harbour of King's Lynn; and for improving and preserving the navigation of the several rivers communicating with the said river Ouze." 59

In his Catalogue of Papers . . 1731 to 1800 , prepared in 1807, Mr. Hansard states in the entry for paper no. 788, that the evidence for the seventh and tenth

\footnotetext{
56 See Catalogue of Papers,; . 1731-1800, introduction to "Accounts and Papers.

57 Mar. 1794, Jour. H. C. XLIX, 271-72.

58 28 May 1794, ibid., XLIX, 635. On this date a motion to proceed further with the bill for improving the drainage, \&c., passed in the negative.

59 14 Feb. 1794, ibid., XLIX, 166. On this date leave was given Sir John Wodehouse and Mr. Coke of Norfolk to prepare and bring in a petition for the "Eau Brink and King's Lynn drainage bill."
}

COLLEGE AND RESEARCH LIBRARIES 
days of the committee hearings on the petition for the "Eau Brink and King's Lynn drainage bill" is missing. This entry indicates that Hansard had succeeded in locating all of the paper except the evidence for the two days. The seventh day was probably 19 March 1794 and the tenth day was probably 27 .March 1794, for these dates check with the known dates of the sixth, eighth, ninth, and eleventh days of the hearings, and with dates listed in the Journals on which hearings were held. ${ }^{60}$ The House ordered the evidence taken by the committee to be printed from time to time on 4 March $1794,{ }^{61}$ and the complete official edition of the paper totaled 568 pages consecutively foliated. Since the missing printed portions of the edition for the seventh and tenth days were pages 283-340 and 407-442, respectively, it may be assumed that the evidence for those days was actually printed.

Notwithstanding the rather conclusive evidence that Hansard located all of paper no. 788, except that for the two days, there is, on the other hand, almost equally conclusive evidence in the lacunae of the original Abbot Collections that indicates that he also failed to locate other portions of the paper as well. For instance, the Abbot Collection at the British Museum contains only pages 135241 , the evidence for the fifth day; the House of Commons set is not much more complete; and the Speaker's Gallery set at University College lacks the entire paper no. 788 in its bound Vol. XXXIX, Accounts and Papers. In the face of these lacunae in the original Abbot Collections, the prospects were remote for obtaining this paper for the Readex microprint edition. An intensive search, featured by countless dead ends and a final

60 Jour. H. C., XLIX, 353, 387. The first page reference probably refers to the seventh day of hearings, and the second to the tenth day of the committee hearings, on the Eau Brink and King's Lynn drainage bill. The action on $18 \mathrm{March} 1794$ (the sixth day) is on page 350 ; that of 20 March, (the eighth day) on pages 356-57: that of 20 March, (the eighth day) on pages $356-57$; that of the eleventh day, 2 April 1794 on page 411 . 614 Mar. 1794, Jour. H. C., XLIX, 290-91. jackpot, has finally resolved most of the problem. Almost simultaneously, as the end of a long list of possible sources drew near, single copies of the paper, minus the evidence of the seventh and tenth days, were located at the House of Lords in their incomplete Abbot Collection, and at the University College among unbound miscellaneous papers that certainly were not a part of the Speaker's Gallery set. Although a search for the missing two days of the paper continues, ${ }^{62}$ the specifications of the paper no. 788 for the Abbot Collection in the Catalogue of Papers have been met in the microprint edition.

The final problem of collating the Accounts and Papers of the Abbot Collection concerns paper no. 923, Land Tax, 1798- Propositions; and no. 924a, Land Tax, 1798-Resolutions. In 1798 parliament passed "An act for granting an aid to His Majesty, by a land tax, for the service of the year one thousand seven hundred and ninety-eight. ..."63 The war with France had been going on for five years and the country was confronted with the problems of financing the war. In the way of implementing the act granting the land tax, the Treasury laid before Commons a group of fifteen propositions which provided that several "sums of money shall be charged on the counties and places in Great Britain, in respect of premises, . . . to be raised, levied and paid unto His Majesty within the space of one year trom 25 th day of March 1798, and [shall] from and after the expiration of the said term, continue to be raised, levied, and paid yearly to His Majesty, His Heirs, and successors, from the 25th day of March in every year forever. ..."64 The propositions became resolutions by the addition of an introductory clause, "Resolved that it is the

62 The county archives at Lincoln, Norwich, and Cambridge, all directly in or near to the Bedford level areas, have reported that the missing portions of paper no. 788 are not in their collections.

63 "Land Tax, 1798, Propositions," H. C. Sess. Paps., 1731.1800, Accounts and Papers, XLV, no. 923, par. 1 . 64 Ibid. 
opinion of this committee," to each of the propositions. ${ }^{65}$ Each of the three Abbot Collections contains no. 923 (10p.); none contains no. 924a, which is listed in the Catalogue of Papers as being the same as paper no. 923; and in each of the collections the tables of contents of Vol. XLV, Accounts and Papers, list 924a as being "out of print;" and all three collections contain no. $924 b$ (10p.).

The question that arises is whether there really ever was a paper no. 924a, Land Tax, 1798-Propositions, in view of the fact that no. 923 is listed as being of the same year and identical in title. The Journals and the Votes of the House do not contain the answer, but information supplied by the staff of the Treasury and Cabinet Office Library, after a careful study of the treasury papers in the special collection of Accounts and Papers held by the library, provides a basis for a resolution of the problem. In the volume of papers in the library for 1796-97 -1797-98, there are but two papers, Land Tax, 1798-Propositions, and Land Tax, 1798- Resolutions. These papers are the same in text as nos. 923 and $924 \mathrm{~b}$ of the Abbot Collection. Since the Accounts and Papers collected and maintained for the Treasury do not contain what would be, if it ever existed, a treasury paper no. $924 \mathrm{a}$, and since the staff of the library supports the conclusion that there is no basis for a paper so numbered, the paper no. $924 \mathrm{a}$ is being deleted from the Abbot Collection.

\section{Nineteenth-Century Sessional Papers}

Only seventeen papers of the nineteenth-century collection of the Sessional Papers remained to be located in England in 1959. That is not to say that the task of collating the sixty-five thousand House of Commons Papers and the fourteen thousand Command Papers that compose this collection had presented

as "Land Tax, 1798, Resolutions," $H$. C. Sess. Paps., 1731-1800, Accounts and Papers, $X L V$, no. $924 \mathrm{~b}$; and 16 April 1798, Jour. H. C., LIII, 459-62. only seventeen problems; the problems had been countless but the work had been spread over such a long period that time had permitted the widespread inquiries for missing papers to turn up the ones not located in the New York Public Library. It is not within the scope of this article to recapitulate the solution of other than difficult collation problems in the last phase of the program. Of the seventeen papers to be located in England, five required considerable time and effort; the other twelve were found in various nineteenth-century collections in England.

The first of the problems concerned paper no. 122, 2 June 1802, “A Sermon to be preached before the Honourable House of Commons at the Church of Saint Margaret, Westminster, on Tuesday, June 1, 1802, being the Day appointed for General Thanksgiving." The occasion for thanksgiving was peace with France, and on 21 May 1802 the Reverend Dr. Vincent was invited by the House to preach the sermon. ${ }^{66}$ That he performed the honor is confirmed by the expression of thanks the House voted to Dr. Vincent on 2 June, and by the order that the sermon was to be printed. ${ }^{67}$ The sermon was not printed in the Journals, and it has not been found in any of the better collections of the papers. That it belongs in the 1801-2 series of papers is evidenced by the order for printing, by the listing of the paper in the general indexes of the Sessional Papers as no. 122 of 1801-2, without a volume assignment, and by an item in The London Chronicle to the effect that the Commons held a thanksgiving service in Saint Margaret's and the Lords in Westminster Abbey. ${ }^{68}$ The Times of London made no mention of the occasion.

Interesting as the leads confirming the sermon were, they did not turn up the

60 Votes of the House of Commons, 1801-2, No. 118, p. 1135 ; Jour. H. C. LVII, 483.

- 67 Jour. H. C., LVII, 533.

as The London Chronicle (1 to 3 June 1802), 521. 
text of the sermon itself. This discovery came from biographical data in Watt's Bibliotheca Britannica, identifying Vincent as Dr. William Vincent, Dean of Westminster, who preached the thanksgiving sermon of 1 June 1802, which was printed. ${ }^{69}$ With this information the sermon was located at the British Museum in a volume entitled, Thanksgiving Sermons, B-V. ${ }^{70}$ The sermon was entitled " 'A Sermon Preached before the Honourable House of Commons at the Church of Saint Margaret, Westminster on Tuesday June 1, 1802, Being the Day Appointed for a General Thanksgiving.' By William Vincent, D.D. Printed by Luke Hansard, Lincoln's Inn Fields; and sold by T. Cadell, Jun. and W. Davis, in the Strand, 1802." The sermon consists of thirtythree pages and is the last in the volume. This text is being reproduced for the microprint edition and will be located at the end of Vol. IV, 1801-2, immediately following paper no. 48, "Vote of Thanks to the Local Militia and Volunteers."

Problems two and three pertain to votes of thanks of the House to militia, local militia and volunteers made on 6 April 1802,71 on the occasion of the peace in that year, and on 6 July 1814,72 on the occasion of the overthrow of Napoleon. Both actions are recorded in the Votes and Journals, together with the resolutions of thanks, which were to be sent to the lord lieutenants of each country, riding, and place in Great Britain and to the Lord Lieutenant of Ireland, over the signature of the Speaker of the House. The first vote of thanks is entered in the General Index. . . ., 1801-183273 as paper no. 48 , "Vote of Thanks to the

\footnotetext{
69 Robert Watt. Bibliotheca Britannica (Edinburgh, 1824), II, $935 \mathrm{k}$.

70 Thanksgiving Sermons, B.V (Brit. Mus. cat. no. 694 , h. 8,25 ).

71 6 April 1802, Votes H. C., 1801-2, No. 87, 801-2. 6 April 1802, Jour. H. C., LViII, 303-4.

${ }^{72} 6$ July 1814, Votes H. C., 1813-14, No. 104, p.

845 . Jour. H. C., LXIX, 438.
73 General Index to Bills, Reports, Accounts and Other Papers, Printed by the Order of the House of Commons, 1801-1832, H. C. Sess. Paps., 1833 (737),
} XI: 253 .
Volunteers and Militia," 1801-2, Vol. IV, p. 631. The second vote of thanks is entered in the same index as "Letter from the Speaker, with Votes of Thanks to Militia, Local Miltia and Volunteers," 1813-14, Vol. XI, p. $140 .{ }^{74}$ The thanks in each instance were in the form of four resolutions: one to the officers and one to the non-commissioned officers and men of the militia, and one to the officers and one to the noncommissioned officers and men of the local militia, yeomanry, and volunteers. Neither of the above votes of thanks of the House appear as separate papers in any of the nineteenthcentury collections. However, since the votes were printed in both the Votes and Journals of the House, the resolutions that express the thanks in 1802 and 1814 , respectively, are being blocked out, microcopied, and reproduced in the microprint edition.

The finding of the complete text of paper no. 140, Controverted Election Petitions, 1806-07, was the fourth problem of collation in the last phase. The paper consisted of three parts, but Sessional Papers collections in the Western Hemisphere and in the United Kingdom, it appeared, at best contained only parts two and three. Part two, 26 March 1807, listed the names of the constituencies for which controverted election petitions were being filed, the petitioners, the members sitting for the constituencies, the dates the committees for investigating the petition were appointed, and the determinations of the petitions. Part three, 27 April 1807, contained the same list of petitions as two, but it was more complete with respect to the determination of the cases. In the light of the foregoing data one was strongly tempted to conclude that part one of paper no. 140 probably was only a paper showing the initial action on the petitions listed in parts two and three. The Journals did not reveal that there were three parts to the paper, let alone distinguish be74 Ibid. 
tween them. It looked as though paper no. 140 would appear in microprint in two parts only, with a note to the effect that it probably was an abridgement consisting only of parts two and three. As a last resort inquiry was made of the House of Lords Library, and there part one was found. Contrary to presumption part one contained an entirely different list of election petitions from those in parts two and three. Only by the narrowest of margins was this paper located in complete text for the Readex microprint edition. ${ }^{\mathbf{7 5}}$

In 1807 a committee of Commons was appointed to examine and consider what regulations had been established in order to control the several branches of public expenditure in Great Britain and Ireland. The committee was also to consider the effectiveness of the regulations and what further measures were necessary for reducing any part of the public expenditure or for diminishing the amount of salaries and emoluments without detriment to the public service. In addition to reports on "the pay office" and "the bank," the First Report and the Second Report, respectively, the committee made a Third Report on offices, sinecures, places, and pensions. In connection with this Third Report,

75 Controverted Election Petitions, 1806-7, Nos. 1, 2 , 3 ; H. C. Sess. Paps., 1806-7 (140), pp. 1-10, III :497$3 ; \mathrm{H}$. which was ordered to be printed on 10 August $1807,{ }^{76}$ there was printed an un. numbered, and in the indexes undated, paper entitled Schedule of Requisitions of six pages. The paper was assigned to Vol. II, 1807, beginning at page 435, immediateely following the Third Report to which it was directly related.77 This Schedule of Requisitions was missing from all of the major collections of the nineteenth-century Sessional $\mathrm{Pa}$ pers examined in the Western Hemisphere and in the United Kingdom. The fact that the paper was unnumbered, that the Journals supply no specific information about it, and that it is missing in so many major collections of the Sessional Papers aroused the thought that the paper might never have been printed. Once again, however, the final search yielded the desired results, and again at both the House of Lords and Treasury and Cabinet Office Libraries was the paper found. With this find the collation of the nineteenth-century sessional papers was completed, and with the Abbot Collection already taken care of, the curtain can be lowered on the program of collation and publication that was begun twenty years ago.

${ }^{76}$ Third Report from the Committee on Public Expenditures in Great Britain and Ireland; $\mathrm{H}$. C. Sess. Paps., 1807 (109), pp. 1-12, II :423-34; 10 Aug. 1807, Votes H. C., No. 40, p. 106; Jour. H. C.. LXII:836.

77 Schedule of Requisitions from the Sclect Committee on Public Expenditures; H. C. Sess. Paps., 1807 (0), pp. 1-6, II :435-40.

\section{Applications for ACRL Grants}

Forms on which applications for grants in ACRL's Grants Program for 1960/61 may be submitted have been distributed. They have been sent to all college and university libraries presumed to be eligible in the program on the basis of the information recorded in "Higher Education," part 3 of the Education Directory published by the U. S. Office of Education. Any eligible library that has not yet received the forms should request them from the ACRL office. 